\title{
Manipueira como promotor do desenvolvimento radicular de mandioca Manihot esculenta Crantz
}

\section{Manipueira (cassava wastewater) as promoter of root development of cassava Manihot esculenta Crantz} \author{
Glaucia Almeida Morais² \\ ${ }^{1}$ Universidade Federal da Grande Dourados - UFGD \\ ${ }^{2}$ Universidade Estadual de Mato Grosso do Sul - UEMS
}

Antonio Souza Silvaํ, Nahara Gabriela Piñeyro ${ }^{1}$, Jônatam Moreira Rodrigues ${ }^{1}$, Edmar Souza Silva²,

\begin{abstract}
Resumo
A manipueira é um tipo de efluente orgânico oriundo da indústria de mandioca (Manihot esculenta Crantz). No entanto este resíduo apresenta diferentes tipos de nutrientes que podem contribuir com a qualidade do solo e consequentemente da planta. Assim, o objetivo deste estudo foi investigar o efeito da manipueira e fertilizante como promotor de enraizamento de estacas. Este efeito foi avaliado no desenvolvimento inicial da planta de mandioca. As estacas foram imersas em: água (controle negativo); Manipueira e fertilizantes (controle positivo). Após o experimento, os dados foram submetidos à análise de variância ANOVA. O uso da manipueira proporcionou maior número e comprimento de raizes, também foi observado o aumento do ganho de peso da parte aérea da planta. Concluiu-se que manipueira aumenta o desenvolvimento da raiz, na variedade de "Fécula-branca", especialmente em comprimento, funcionando como um bio-estimulador de enraizamente de manivas de mandioca.
\end{abstract}

Palavras-chave: Resíduos agro-industriais, indutor de enraizamento, promotor de enraizamento de estacas.

\begin{abstract}
Manipueira is an organic wastewater produced of the cassava (Manihot esculenta Crantz) industry. However this residue has different types of nutrients that can contribute to the quality of the soil and consequently of the plant. The objective of this study was to investigate the effect of Manipueira and fertilizer as cuttings rooting promoter. This effect was evaluated in the initial development of cassava. The cuttings were immersed in: water (negative control); Manipueira and fertilizer (positive control). After the experiment, the data were submitted to ANOVA. The use of Manipueira provided larger number and root length, also was noted the increased weight gain of the aerial part of the plant. It was concluded that Manipueira increases root development in the variety of "Fécula-branca", especially in length, functioning as a bio-stimulator of cassava plants.
\end{abstract}




\section{Introduction}

$\mathrm{T}$ here are numerous cultures as sources of carbohydrates. However countries seek the cultures with low production cost that fit well with the climatic conditions, soil and rainfall. The cassava plant Manihot esculenta Crantz is semi-shrub belonging to the Euphorbiaceae family, has agametic propagation, multiplying through segments of the stem, branches or cuttings - cuttings (Alves et $a l, 2009$ ). The use of cuttings of good quality has direct influence on productivity growth. Studies have shown increases of up to $30 \%$ in the production of root without changing other cultural practices and use of inputs (Rodrigues et $a l, 2008)$.

The cuttings seeds, used for the spread of the cassava plant are parts of tops with an average length between 12 to 15 centimeters. Usually the seed - stalks are good origin of cassava plants obtained from the first cycle of crop development, because in this period the plants have high nutritional reserves and supply of good quality planting material. The crude seedlings from aged to eighteen months are subject to insect attack by pathogens and reduced sprouting due to lignification of tissues (Alves et al, 2009).

Low root density $\left(<0.2 \times 10^{-2} \mathrm{~mm}^{3}\right)$, plant length lower than $1 \mathrm{~km} \cdot \mathrm{m}^{-2}$ and root concentrations in shallow are factors that contribute to the limitations on the productivity (Ofori 1970; Connor et al, 1981). In this context, under optimal conditions, the culture in the city of Ivinhema has produced on average 50 tonnes per hectare. The more productive varieties of cassava oriented industries can produce on average 22-49 ton/ha of fresh roots (Sukmadjaja and Widhiastuti, 2011). There is great potential for further increases in production under ideal conditions, the yields of cassava can reach 80 ton/ha, compared with the current world average yield of only 12.8 ton/ha (FAO, 2014).

The increasing industrialization of food worldwide is steadily increasing the amount of waste which, when not reused resulting damage to the environment. It is for this reason that the use of these agro - industrial waste has drawn attention worldwide, contributing to good conservation practices and environmental sustainability. Manipueira, considered a by- product or residue of industrialization of cassava, presents itself physically in the form of suspension and, chemically, as a smorgasbord of compounds, such as gum $(5-7 \%)$, glucose and other sugars, proteins, squamous cells, derived cyanogenic linamarin and cyanide (hydrocyanic acid, cyanide and aldehydes), several different organic substances and minerals that lend themselves as macro and micronutrients vegetables (Magalhães, 1993).

Has been used in several studies as nematicide, miticide, fungicide, bactericide, herbicide, irrigation and fertile biopesticides (Ponte 1999; Silva et al, 2007). Measures to increase crop productivity without increasing the cost of production must be developed. The objective of this study was to evaluate and compare the effect of Manipueira and a fertilizerbased Macro - Micro Nutrients in the early development of cassava.

\section{Material and Methods}

The experiment was conducted in the premises of Sitio Bela Vista, City of Ivinhema MS. Manivas-seed "Fécula-branca" cultivar, from a crop cycle with a mean basal diameter of $30.92 \mathrm{~mm}$ and $20.98 \mathrm{~mm}$ apical and $1.70 \mathrm{~m}$ in length were used. The stems were removed to 4 days before, $1.35 \mathrm{~m}$ or ${ }^{3 / 4}$ of the total length of tops in use. The use of cuttings with this diameter is justified because (Golla et al, 2010), would provide much more homogeneous stands and seedlings with greater development.

The experimental design was a randomized block design (RBD) with four replications. The cuttings were immersed for 2 minutes in the following ways:1. Negative control - water 2. Manipueira (cassava wastewater) - diluted in water (1:1) 3. Positive control - fertilizer being applied based on the manufacturer's recommendation for foliar application in cassava a dosage of $\left(2 \mathrm{~L} / 300 \mathrm{~L} \mathrm{H}_{2} \mathrm{O} / \mathrm{ha}\right)$ dose. The composition of the fertilizer used was as follows: macronutrients $\left(\mathrm{N}, \quad \mathrm{P}_{2} \mathrm{O}_{5}, \quad \mathrm{~K}_{2} \mathrm{O}_{2} \mathrm{~S}\right)$ and micronutrients $(\mathrm{Fe} \%, \mathrm{Mn} \%, \mathrm{Cu} \% \mathrm{Zn} \%, \mathrm{~B} \%$, $\mathrm{Mo} \%$ ).

The planting was held on 03 October 2009 and each cutting was properly labeled to observe the development of each part of the raw, considering three fractions / parts to this study: baseline 1st, 2nd median; apical 3rd. The $15 \mathrm{~cm}$ 
in length cuttings were randomly allocated into 1 $\mathrm{m}^{2}$ planted horizontally in washed sand and covered with a layer of three $\mathrm{cm}$ from the same sand. Since washed sand that does not provide any nutrient for plant, it is simply a medium of support and safe water. 46 days after planting (DAP), the experiment was completed and the data evaluated after removal of plants, being sectioned the root system of each plant for counting the number of roots and measurement of length, dry weight of roots and mass dry the shoot. The results were subjected to analysis of variance by the Scott - Knott test at 5\% probability.

\section{Results and Discussion}

Starch - white dipping cuttings of cassava variety Manipueira provided greater number of roots per fraction of branches 60.14 (Table1). Comparing the three fractional parts of raw material, there was a decrease in the number of root apical to basal part in all treatments 52.32 25.07 (Table 1).

The use of fertilizers significantly increases productivity per hectare, increasing net economic gain (Pypers et al, 2011). On average the cost of a ton of chemical fertilizer NPK formulation $(04-30-10+3 \% \mathrm{ZN})$ is $\mathrm{U} \$ \mathrm{~S} 505.08$ (American dollars) (FAEG, 2014), after conversion of Brazilian Reals into American Dollars (BM \& F BOVESPA, 2014). The national average price per ton of cassava in Brazil at the reference date: March 10, 2014, is U\$S 148.72 (BM\&F BOVESPA, 2014; AGROLINK, 2014). The exchange ratio of agricultural output needed to acquire a ton of fertilizer is 3,396 tons of cassava / ton of fertilizer. Compared to the current world average yield of just 12.8 tonnes per hectare (FAO, 2014). With the increase of cassava only provide better productivity at low cost to cassava producers in regions with low production technology.

Becomes a high cost to acquire a ton of cassava. The use of Manipueira (cassava wastewater) increases the initial number of roots at low cost. Since it is a waste without value, can be further marketed by starch producing undertakings as another a by-product of cassava. With the increase in root number, better absorption of nutrients deposited in rows of crops could be collected.

The absence of application of any of the three elements (NPK) resulted in reduced the productivity in subsequent cultures, demonstrating the importance of each element and, applied together provides an increase of $10.7 \mathrm{t} \mathrm{ha}^{-1}$ of cassava in the next culture (Molina and El-Sharkawy, 1995). In the absence of application of NPK fertilizer in the previous crop, the immersion of Manipueira cuttingsseeds (rich in these elements) could supply the deficiency of nutritional reserves of the plant at planting. Moreover, Manipueira can increase the number of roots without interfering with the sprouting cuttings (Table 1). The effect of auxin on the cassava variety Darul Hidayah provided on average only 4.86 roots per shoot at 15 days after planting (Sukmadjaja and Widhiastuti, 2011). Was possible to obtain $94 \%$ more yield in cassava productivity in cassava cultivation using (5 L per linear foot or 50 cubic meters ha-1) (Diniz et al, 2009). Treatment with fertilizer inhibited formation of roots in all fractions of the raw, introducing phytotoxic effect at the concentration used (Table 1). Not appropriate concentrations of biostimulant, Chlorocholine Chloride (CCC) and Paclobutrazol (PBZ) also inhibit the formation of cassava roots (Feltran et al, 2009; Medina et al, 2012). The treatment of cuttings of cassava agro - industrial waste can contribute to increased productivity in cassava with low production cost.

About development in length of roots, Manipueira $51.26 \mathrm{~cm}$ and fertilizer $48.01 \mathrm{~cm}$ showed higher root length when used cuttings from basal and medial part of the plant (Table 2). At the concentration of $750 \mathrm{ml} \mathrm{ha-1}$ the biostimulant is provided a root length of $10,40 \mathrm{~m}$ (Feltran et al, 2009). However fractional parts of the three raw decreased root development of the basal portion to the apical for all treatments (Table 2) were observed. The use of cuttings the basal part of the raw compared with the apical part promoted greater root length, favoring the cultivation of the soil by the root system. At the concentrations used, the (CCC) did not provide greater lengths of tuberous roots and paclobutrazol (PBZ) reduced the root length regardless of the applied dose (Medina et al, 2012). 
Table 1. Effects of cassava wastewater and Fertilizer in the number of roots of cassava cuttings. Immersion time the cuttings were 2 minutes for each treatment. The following values were obtained after 46 days of planting. Ivinhema (MS), Brazil. 2014.

\begin{tabular}{lllll}
\hline & Basal $(\mathrm{N} / \mathrm{M})$ & Median $(\mathrm{N} / \mathrm{M})$ & Apical $(\mathrm{N} / \mathrm{M})$ & \\
\cline { 2 - 4 } Negative control & $52.32 \pm 6.13 \mathrm{Ab}$ & $34.32 \pm 5.64 \mathrm{Ba}$ & $25.07 \pm 3.02 \mathrm{Cb}$ & \multirow{2}{*}{$10.51^{1}$} \\
Manipueira & $60.14 \pm 3.78 \mathrm{Aa}$ & $37.96 \pm 4.46 \mathrm{Ba}$ & $31.53 \pm 5.22 \mathrm{Ca}$ & $6.93^{1}$ \\
Positive control & $31.84 \pm 3.78 \mathrm{Ac}$ & $24.00 \pm 2.71 \mathrm{Bb}$ & $17.69 \pm 3.31 \mathrm{Cc}$ & $10.65^{1}$ \\
\hline & $6.33^{*}$ & $12.07^{*}$ & $11.24^{*}$ & $\mathrm{CV} \%$ \\
\hline
\end{tabular}

${ }^{1}$ Means followed by the same capital letter in the line and lowercase letter in column do not differ by the Scott-Knott test at $5 \%$ probability. $\mathrm{N}$ being the number of roots and $\mathrm{M}$ cuttings of cassava.

Table 2. Effects of cassava wastewater and Fertilizer in the root elongation of cassava cuttings. Immersion time the cuttings were 2 minutes for each treatment. The following values were obtained after 46 days of planting.

\begin{tabular}{lllll}
\hline & Basal $(\mathrm{C} / \mathrm{M})$ & Median $(\mathrm{C} / \mathrm{M})$ & Apical $(\mathrm{C} / \mathrm{M})$ & \\
\cline { 2 - 4 } Negative control & $47.38 \pm 3.67 \mathrm{Aa}$ & $43.63 \pm 6.06 \mathrm{Aa}$ & $41.34 \pm 4.50 \mathrm{Aa}$ & \\
Manipueira & $51.26 \pm 2.22 \mathrm{Aa}$ & $44.11 \pm 3.27 \mathrm{Ba}$ & $41.90 \pm 4.00 \mathrm{Ba}$ & $7.81^{2}$ \\
Positive control & $48.01 \pm 2.59 \mathrm{Aa}$ & $45.50 \pm 1.62 \mathrm{Aa}$ & $40.97 \pm 1.54 \mathrm{Ba}$ & $5.14^{2}$ \\
\hline & $6.35^{\mathrm{ns}}$ & $10.09^{\mathrm{ns}}$ & $8.59^{\mathrm{ns}}$ & $\mathrm{CV} \%$ \\
\hline
\end{tabular}

${ }^{2}$ Means followed by the same capital letter in the line and lowercase letter in column do not differ by the Scott-Knott test at $5 \%$ probability. ns not significant. $\mathrm{C}$ being the length of roots and $\mathrm{M}$ cuttings of cassava.

The more developed root system can compensate for the low availability of nutrients or water in the soil, favoring the development of the plant (Feltran et al, 2009). In the literature it was found that corn plants Zea mays L., when grown in soil fertilized with Manipueira, promoted higher growth, green weight and production Franco and Ponte (1988), a fact that was evidenced in the application of Manipueira in cassava plants, but in the absence of fertilization with micro-and macro - nutrients such dosage (2L/300 $\left.\mathrm{L} \mathrm{H}_{2} \mathrm{O} / \mathrm{ha}\right)$.

The use of 0.1 and $1.0 \mathrm{mg} / \mathrm{L}$ auxin gave longer cassava roots of the varieties tested, providing a daily growth (day to $0362 \mathrm{~cm}$ ) 15 days after planting (Sukmadjaja and Widhiastuti, 2011). Since the use of auxin promotes better root development (Mingxia et al, 2011). The growth rates of seedlings of cassava are significantly different in several genotypes and environments (Aladele and Kuta, 2008).

Thus, Manipueira (cassava wastewater) demonstrates potential to increase the productivity of cassava since it increases root length, making this byproduct of pressing the cassava root as a hormonal biostimulator of cassava plants. The use of the basal portion of the raw provided to increase the number of roots. The fertilizer used resulted in lower number of roots per cutting observed, indicating phytotoxicity at the concentration used. This work constitutes the starting point for further studies, which fits great concentration of industrial waste to optimize production.

\section{Acknowledgments}

To the Fecularia Pantanal Indústria e Comércio Ltda for providing the study material for this research. To the Coordenação de Aperfeiçoamento de Pessoal de Nível Superior (CAPES), for the doctoral scholarship to the first author. 


\section{Referências}

AGROLINK. Cotações de mandioca. Available in $<$ http://www.agrolink.com.br/cotacoes/divers os/mandioca $>$ acessed on 11/04/2014.Ferrari, S. L. P., Cribari-Neto, F. (2004). Beta regression for modelling rates and proportions. Journal of Applied Statistics, 31(7), 799-815.

ALADELE, S. E.; KUTA D. D. Environmental and genotypic effects on the growth rate of in vitro cassava plantlet (Manihot esceulenta). African Journal of Biotechnology, v. 7, p. 381385, 2008.

ALVES, J. M. A.; ARRUDA, K. R.; RODRIGUES, G. S.; UCHÔA, S. C. P.; ALBUQUERQUE, J. A. A. Brotação de manivas para a propagação rápida da mandioca. Raízes Amido Tropical, v. 5, p. 280-284, 2009.

BM\&F BOVESPA. A nossa bolsa. Available in $<$ http://www.bmfbovespa.com.br/shared/ifra me.aspx?altura $=1000 \&$ idioma $=$ ptbr\&url=www2.bmf.com.br/pages/portal/bmfb ovespa/clearing1/Cambio/cotacoes/cotacoes.a sp $>$ acessed on 10/03/2014.

CONNOR, D. J.; COCK, J. H.; PARRA, G. E. Response of cassava to water shortage. I. Growth and yield. Field Crops Research, v. 4, p. 181-200, 1981.

DINIZ, M. S.; FARIAS, M. A. A.; TRINDADE, A. V.; LEDO, C. A. S. Efeito da manipueira na adubação da mandioca. Raízes Amido Tropical, v. 5, p. 416-421, 2009.

Federação da Agricultura e Pecuária de Goiás (FAEG). Available in < http://sistemafaeg.com.br/mercados-ecotacoes/outros/fertilizantes $>$ accessed on $11 / 05 / 2014$.
Food and Agriculture Organization of the United Nations (FAO). Save and Grow. Cassava: A Guide to Sustainable Production Intensification. 2014. Available in < http://www.fao.org/docrep/018/i3278e/i3278e. pdf $>$ accessed 02/05/2014.

FELTRAN, J. C.; VALLE, T. L.; GALERA, J. M. S. V. Efeito de bioestimulante (STIMULATE) no desenvolvimento radicular da mandioca de indústria variedade IAC-14. Raízes Amido Tropical, v. 5, p. 702-706, 2009.

FRANCO, A.; PONTE, J. J. Subsídios à utilização da manipueira como nematicidas: dosagem e interferência na fertilidade do solo. Nematologia Brasileira, v. 12, p. 35-45, 1988.

GOLlA, A. R.; SILVA, A. C.; NARITA, N. Influência do diâmetro da maniva no desenvolvimento inicial de plantas de mandioca. APTA Agencia Paulista de Tecnologia e Agronegócios, 2010.

MAGALHÃES, C. P. Estudos sobre as bases bioquímicas da toxicidade da manipueira a insetos, nematóides e fungos. Dissertação de Mestrado, Universidade Federal do Ceará, Fortaleza, p. 117, 1993.

MEDINA, R.; BURGOS, A. (EX AEQUO). DIFRANCO, V.; MROGINSKI, L. P.; CENÓZ, P. Effects of chlorocholine chloride and paclobutrazol on cassava Manihot esculenta (Crantz cv. Rocha) plant growth and tuberous root quality. Agriscientia, v. 29, p. 51-58, 2012.

MINGXIA, F.; ZAOCHANG, L.; LIGUO, Z.; TIAN, L.; YUNHUA, L.; LIJUN, L. Effects of Plant Growth Regulators and Saccharide on In Vitro Plant and Tuberous Root Regeneration of Cassava (Manihot esculenta Crantz). Journal of Plant Growth Regulation, v. 30, p. 11-19, 2011. 
MOLINA, J. L.; EL-SHARKAWY, M. A. Increasing crop productivity in cassava by fertilizing production of planting material. Field Crops Research, v. 44, p. 151-157, 1995.

OFORI, C.S. Absorption and translocation of phosphate through cassava tubers (Manihot esculenta Crantz). Journal Agricultural Science, v. 3, p. 203-205, 1970.

PYPERS, P.; SANGINGA, J. M.; KASEREKA, B.; WALANGULULU, M.; VANLAUWE, B. Increased productivity through integrated soil fertility management in cassava-legume intercropping systems in the highlands of Sud-Kivu, DR Congo. Field Crops Research, v. 120, p. 76-85, 2011.

PONTE, J. J. Cartilha da manipueira: uso do composto como insumo agrícola. SECITECE Fortaleza Ceara, CE, Governo do CE, ed. Assis Almeida Ltda, p. 53, 1999.

RODRIGUES, A. R.; ALVES, J. M. A.; UCHÔA, S. C. P.; ALBUQUERQUE, J. A. A.; RODRIGUES, G. S.; BARROS, M. M. Avaliação da capacidade de enraizamento, em água, de brotações, ponteiros e estacas herbáceas de clones de mandioca de mesa. Agro@mbiente Online, v. 2, p. 37-45, 2008.

SILVA, A. S.; SAGRILO, E.; SILVA, E. S.; SILVA, C. S.; MORAIS, G. A. Potencialidade do extrato aquoso de nim e manipueira no controle da mosca-branca em mandioca. Raizes Amidos Tropicais, v. 3, p. 65-68, 2007.

SUKMADJAJA, D.; WIDHIASTUTI, H. Effects of plant growth regulators on shoot multiplication and root induction of cassava varieties in vitro culture. Biotropica, v. 8, p. 50-60, 2011. 